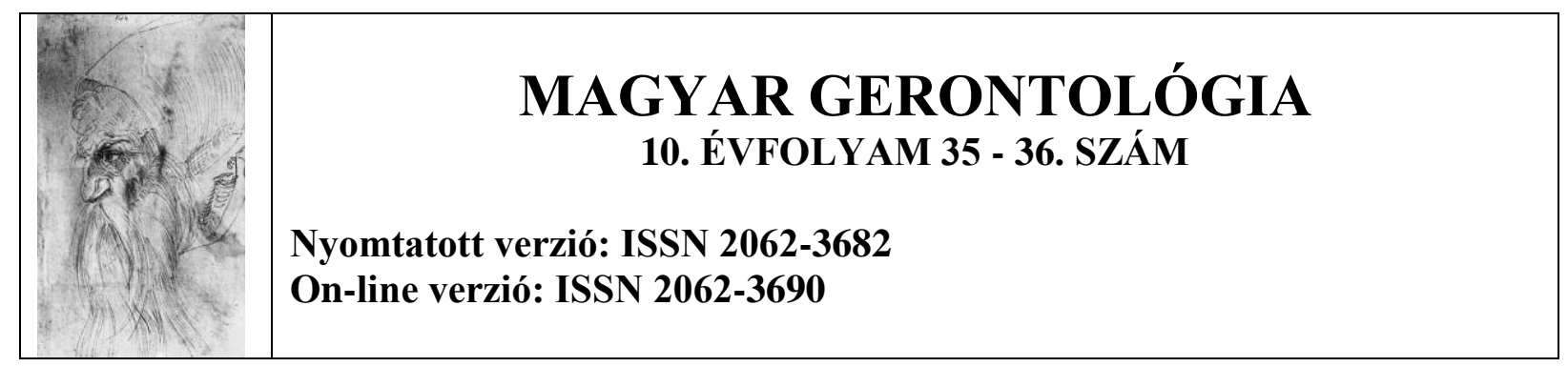

\title{
DEMOKRATIKUS ÉRTÉKEK - DISZKRIMINATÍV GYAKORLATOK, TEKINTETTEL AZ IDŐSKORÚAK STÁTUSÁRA
}

\author{
Prof. Dr. Hell Judit
}

Kulcsszavak: etika, ageizmus, selejtezés kultúrája, generációk szolidaritása

\section{Összefoglalás}

A gerontológiai tudományok müvelése Magyarországon rövid múltra tekint vissza. Talán ezért sokan és tévesen a gerontológia jelentését leszükítik annak biológiai- orvosi típusára. Amellett érvelünk, hogy a humán- és társadalomtudományi gerontológiának is létjogosultsága van. Megmutatjuk, hogy az ember, az idős ember léthelyzetével kapcsolatban a filozófia és az etika milyen sajátos területen vizsgálódik, miben jelölhető meg missziója: elemezzük a nyugati filozófiai gondolkodás történetét, azt, hogy mely nagy erkölcsi eszméket, értékeket munkált ki több ezer év alatt. Ezek az ideák a modern demokratikus társadalmak elvi alapját képezik. Ilyenek: szabadság, egyenlőség, igazságosság, testvériség, emberi méltóság, emberi jogok. A gyakorlatban ezek gyakran sérülnek. Pl. az időseket életkoruk miatt diszkriminálják. Ezzel sérül az egyenlőség és az igazságosság elve, sérül emberi méltóságuk. A gazdaság, politika, kultúra, oktatás, a nemzedékek közötti viszonyok terén hátrányos helyzetük nyilvánvaló. Az etika feladata a nyugati értékek mentén e gyakorlatok elvi kritikája, ezáltal hozzájárulás annak formálásához. A kontinens demográfiai krízisét az Európai Unió korszerü idősügyi politikai intézkedések, támogatások, projektek útján, a klasszikus nyugati értékek őrzése alapján kezeli. 


\title{
Abstract
}

The scientific study of gerontology in Hungary has a short history. Perhaps that is why the meaning of gerontology is erroneously restricted to the type belonging to biology and medical sciences by many. The present study argues that human and social science gerontology does have reasons for its existence. We outline the specific areas of research done by philosophy and ethics in connection with the situation of the existence of people, especially that of the elderly and describe what their mission consists of. We analyse the history of Western philosophical thinking and the moral ideas and values formed by this thinking in thousands of years. The basic principles of modern democratic societies are constituted by these ideas: liberty, equality, justice, brotherhood, human dignity and human rights. In practice these rights are often violated, for example the elderly people are discriminated against their age, which violates their equality and justice as well as human dignity. Their disadvantageous situation is obvious in the economy, politics, culture, education and relations between generations. The task of ethics is the principle criticism of these practices along the Western values thus contribution to the formation of human conditions. The demographic crisis of the continent is viewed by the EU as based on modern age policy, aids, projects and classical Western values.

\author{
Kháron ladikja nem akkor indul velünk \\ midön lezárul és befagy a szem. \\ Zord átkelök soká nyitott szemmel megyünk \\ a végzetes vizen. \\ Esztendökkel elöbb irigy sorsunk behajt \\ $s$ ringat a csónakon, amely \\ - bár nem kedvünk szerint - épp oly gyönyörü part \\ hosszában suhan el; \\ épp oly szép Canale-n s lagunákon, akár \\ a nászutasoké! \\ Hisz minden ugyanaz: az ég, az út, a táj, \\ épp csak-visszafelé! \\ Minden oly gyönyörü, söt - titkosan - ahogy \\ elleng, még gyönyörübb! \\ Olyanformán, mint a dallam attól, hogy ott \\ hagyja a hegedüt. \\ Ülünk barátaink s fáink közt, nevetünk, \\ - vidám vita folyik - \\ s egyszer csak ringani kezd velünk, (csak velünk!) \\ kifelé a ladik. \\ Bölcs, ki e kéjuton, ezen is mosolyog \\ S ha sír is, hála könnyet ont, \\ Hogy hány piazza-t, hány s milyen Casa d'Oro-t \\ Látott, ha nem is lát viszont!
}


Illyés Gyula Kháron ladikján, vagy az öregedés tünetei címü esszéregényét saját költeményének idézett soraival kezdi. Emberlétünk legegyetemesebb élményéröl, az emberi élet végességéről szól. Földi életünk a költészetben is gyakran használt metafora (toposz) szerint tekinthető úgy, mint egy nagy utazás, amelynek során valahol, szinte észrevétlenül, de megkezdődik a visszaszámlálás (de elindul a visszakanyarodás)... Ám a Túlsó partra szerencsés esetben - hosszú úton jutunk át. Nemcsak a halál, hanem az idősödés tényével, időben elnyúló folyamataival is szembesülnünk kell.

Az ember test és lélek, biológiai és társadalmi létező. Sorsunk -mint minden létezőé - a keletkezés, kifejlődés és elmúlás. Életfolyamataink - időben elörehaladó, kiszélesedő, soklépcsős, törvényszerü, és mindannyiunk számára elkerülhetetlen biológiai processzus során - változnak. Lépésről lépésre öregedünk, majd végül megöregszünk. Erről a külvilág és önmagunk felé is kiváltképp és leplezhetetlenül a testi változások jelei tudósítanak. Korábbi önmagunkhoz képest Másak leszünk. Egyszer csak észleljük, hogy egy más, egy idegen arc néz vissza ránk a tükörből. De a rég nem látott barátok, ismerősök külsőnket lopva fürkészöpásztázó tekintete is emlékeztet a könyörtelenül haladó idő elvégzett munkájára.

Ám ne tévesszük szem elől, hogy az ember specifikuma nem biológiai mivoltában, hanem társadalmiságában ragadható meg. Egyrészt kétségtelenül testi-biológiai organizmus, másrészt társadalmi - közösségi létező. A puszta életben maradásra és egészségének fenntartására irányuló alap-, vagy létszükségletei mellett, melyek jórészt bio-szükségletek, s amelyeket persze már szintén nem vadállati, hanem humanizált, mindenkor társadalmilag meghatározott módon és szinten elégít ki (tiszta levegő és víz, megfelelő táplálék, lakás és ruházat; ill. biztonság, természetének és felkészültségének megfelelő aktivitás, fiziológiai egészségének védelme), ezek mellett tehát vagy ezeken fölül vannak olyan pszichikai , mentális-lelki egészségére vonatkozó kulturális-társas szükségletei is, olyan kívánságai, vágyai, amelyek kielégítését méltán várja el élete során. Ilyenek az életerőnk megtartása, ill. fokozása érdekében pl. képességünk kimüvelése, képzettségünknek megfelelő, ill. alkotó jellegű munka végzése, olyan körülmények, amelyek a társadalmi részvételre serkentenek, a családi együvé tartozás, a barátkozás, a szabadidő kulturált eltöltése (mentális értékek). Mindezek kielégítése, a mentális értékek birtoklása pozitív életérzést, örömöt kelt bennünk, hiányuk bánattal, szomorúsággal jár együtt. Önmegvalósításunkra irányuló, azaz legmagasabb rendü, specifikus társadalmi szükségleteinket - egyben hozzájárulva mások hasonló igényének kielégítéséhez is - szociokulturális szükségleteknek nevezzük, ezek kielégítését szolgáló javakat szociokulturális értékeknek. 
Ha tudományos vizsgálódásaink az emberre, szűkebb értelemben itt az idősödő vagy idős emberre irányulnak, nyilvánvaló, hogy őt a maga komplexitásában, általános és egyszerre egyedi sajátosságaival, meghatározottságaival, rá jellemző, humán szükségleteinek összetett és hierarchikus rendszerével ragadhatjuk meg, ill. az ezeket kielégítő emberi javak, értékek vagy épp ezek sajnálatos nélkülözése oldaláról. Ennek értelmében válik nyilvánvalóvá, hogy az öregedés egyrészt emberi fajra jellemző általános jellemzőit, másrészt kultúrákra, ill. személyekre jellemző csoportos vagy egyéni sajátosságait a gerontológia különbözö diszciplínái (élettani, klinikai- orvosi, lélektani, társadalmi, kultúrantropológiai, ökológiai) tanulmányozzák. És persze nélkülözhetetlenek a kapcsolódó szaktudományok, melyek a gerontológiához való viszonyuk alapján ez esetben annak segédtudományai is: ilyenek az egészségtudományok (táplálkozástudomány, rehabilitáció, dietetika, ápolástan, rekreáció, neveléstudományok-gyógypedagógia, jog (polgárjog, alkotmányjog, munkajog, európai jog), jövő-kutatások, demográfia, közgazdaságtudományok, statisztika, szociológia és szociálpolitika, pszichológia-pszichiátria, fogyatékosságtudomány, politikatudományok, nyelv - és kommunikációtudomány, a nemek tudománya, ökológia, irodalomtudományok, történettudományok, teológia stb.

Röviden: a téma érdemben és korszerüen csak sokoldalú, multidiszciplináris megközelitésben tárgyalható.

És mi marad, egyáltalán marad-e saját terület, önálló feladat itt, a filozófiai tudományok számára? Például az etika vagy az alkalmazott etikák (a biomedicinális és a szociális etika ) számára? Minden bizonnyal igen. Legáltalánosabban azt mondhatjuk, hogy ez a misszió, ez a küldetés annak az emberképnek, és azoknak az értékeknek az állhatatos őrzése, közvetitése és képviselete, amelyet immár több ezer éves kultúránk kidolgozott. A bölcseleti gondolkodás számára, miként azt története bizonyítja, nem volt, és ma sincs fontosabb, nincs bonyolultabb kérdés, mint maga az ember. Közismerten a filozófia a legelvontabb szinten vizsgálja azt, hogy mi is az ember. Kik vagyunk, mi végre vagyunk, mi a helyünk a létezők rendjében? Mi számunkra a legjobb élet, azaz miben áll az emberhez méltó élet? Gnoti sze auton! Ismerd meg önmagad! Mintegy 2500 év távlatából ma is halljuk az üzenetet. A nyugati kultúrát az antik-hellenisztikus-római világnak, a zsidó-keresztény vallásnak és a felvilágosodás korának eszméi alapozzák meg. A nyugati fölfogásban az ember (valami) különleges, kitüntetett státusú, és sajátos rendeltetéssel bíró lény minden más létezőhöz képest. Értelmes - eszes, közösségalkotó - társas-társadalmi lény. Arisztotelész koncepciója szerint egy rá jellemző, sajátos télosszal, egy sajátos végcéllal, a legfőbb Jó képzetével rendelkező lény. S e végcél, ez a legfőbb Jó - számára nem más, mint a boldogság, azaz élete során önmaga értelmes 
mivoltának kibontakozatása. Az ember továbbá per definicionem - morális lény. Homo moralis. S csak az ember erkölcsi lény. Életének és minden cselekedetének morális dimenziója is van. Cselekedeteiben, akaratában, döntéseiben szabad. Szabad - ezért felelős. Önmagáért és embertársaiért. Tudása van a jóról és a rosszról. Jóvá, erényessé formálja, azzá dolgozza ki magát, mert nem eleve olyannak születik. Erények gyakorlása nélkül nincs boldog, azaz emberhez méltó élet. Ezért le kell gyürnie veleszületett önzését, agresszivitását, vad természeti hajlamait. Erkölcsi normáknak, azaz együttélési-cselekvési szabályoknak engedelmeskedik. Tehát tudja, hogy nem tehet meg mindent, nem tehet meg bármit embertársaival! A hellenisztikus korszak fogalmazza meg először a kozmopolitizmus, a szélesebb értelemben vett testvéri közösség, tehát közös embervoltunk gondolatát. Eszerint minden ember ugyanannak a nagy univerzumnak lényegileg egyenlö polgára, mikrokozmosz a makrokozmoszban: nincs többé különbség görög és barbár (nem-görög) spártai és athéni, ember és ember között. E fogalom készíti majd elő a keresztény testvériség, a felebarátiság, az Isten előtti emberi egyenlőség eszméjének a befogadását. A késői ókorban, a világpolgáriság eszméjével párhuzamosan, de mintegy annak ellentéteként megszületik (s a későbbi nyugati fejlődésben egyedülállóan naggyá válik) az individuum, az autonóm, a poliszközösségi kötelékek béklyója alól felszabaduló egyén fogalma is. Az egyéné, annak saját szükségleteivel, képességeivel, életmódjával, az élet értelméről vallott elképzeléseinek egyszeriségével. Az újkori európai polgári fejlődés az individuum újbóli történelmi színrelépését, s fölemelkedését hozza. Az egyén végleg megszabadul a korábbi társadalmi fékektől, kötelmektől: a születés, a rend, az öröklött tulajdon, a müveltség, a vallás stb. különbözöségeitöl. Szabadság, Egyenlöség, Testvériség/Szolidaritás -ezek a vezérszavak! A modernitás felfogása szerint minden ember szabadnak születik és azzá lesz, amivé teszi, teremti magát. Megjelenik a sokoldalú, gazdag egyéniség, sokféle készséggel és képességgel, erkölcsi tartással, felelősséggel. Az individuum - személy, aki hisz saját jövőjében, szűkebbtágabb környezete formálhatóságában és nevelhetőségében. A nyugat teremti meg az individuum tiszteletét és méltóságát. Ennek alapja a szabadság. Az ember individualitásában tehát (a keresztény etikusok szerint is) benne foglaltatik méltósága és pótolhatatlansága, akit cselekvéseiben - melyért felelősséget vállal -, nem a tekintély, nem is a despotizmus, nem az önkény, hanem a lelkiismeret vezet. Ahogy Márai mondja: „Ázsia dolga a rajongás és vakhit, Európa dolga a bírálat és önismeret.” De mi is ez az oly sokat emlegetett, az egyes filozófiaietikai problémák boncolgatása során a modernitásban rendre előjövő hivatkozási alap, vagyis az emberi méltóság? Ez az a fogalom az etikában, jogban, jogfilozófiában, mely egyedül az embernek, mint erkölcsi személyiségnek a feltétlen értékét hivatott jelölni. Emberlétünknek 
tehát legalapvetőbb értéke, mely minden személyt egyenlően és feltétel nélkül, születésétől fogva megillet, sérthetetlen, elidegeníthetetlen, amelyet nem alázhatunk meg, amelynek feltétlen tisztelettel kell adóznunk. Forrása: eszes mivoltunk, akarati és cselekvési szabadságunk, önmagunkért és másokért vállalt felelősségünk, lelkiismeretünk szerint a saját magunknak hozott - vagy Istentől eredeztetett - erkölcsi törvényeknek való engedelmességünk, egyediségünk (mindannyian személyek, egyszeri és megismételhetetlen példány vagyunk). Képesek vagyunk önerőnkből a fejlődésre, az emberebb emberré válásra. A felvilágosodás és a nyugati gondolkodás egyik legnagyobb erkölcsfilozófusa, Immanuel Kant az embert önértéknek ('magánvaló célnak') tekinti, aki csak cselekvésünk célja , de sohasem pusztán eszközünk lehet. Ez az önérték az, mely méltóságának alapja, ami megkülönbözteti öt a javaktól, melyek eszközléttel bírnak, kicserélhetők, helyettesíthetők, pótolhatók, és piaci áruk van. Az ember viszont semmi által nem pótolható, értéke pénzben nem mérhető, nincs ára, mert meg nem fizethető méltósággal rendelkezik. Ez feltétlen tiszteletet követel, így a másikat tárgyként, eszközként (saját érdekeink, boldogulásunk eszközeként) sohasem kezelhetjük! Különben méltóságában alázzuk meg! Ma a demokratikus államok alkotmányai rögzítik az emberi méltóság elvének sérthetetlenségét, s ebből, mint formális érték-kategórából vezetik le konkrét szabályokba foglaltan az egyes tartalmi értékeket, az alapvető emberi jogokat. Ez utóbbiak nem 'jogi jogok', hanem erkölcsi tartalmúak, emberi kiteljesedésünkhöz, boldogulásunkhoz nélkülözhetetlen szabadságjogok. Csak néhány ezek közül: Minden embernek egyenlő joga és (egyenlő) méltósága van. Kell, hogy az emberek egymással testvéri szellemben viseltessenek, azaz egymással szolidárisak legyenek (Schiller Örömódája: Egy-testvér lesz minden ember...). Minden személynek joga van az élethez (avagy az életben-maradáshoz), a szabadsághoz, a személyi biztonsághoz, a tulajdonhoz, a közügyek intézéséhez, a szociális biztonsághoz, a munkához, a méltányos bérhez (nyugdíjhoz), életszínvonalhoz és szabadidőhöz, a neveléshez, és legalább az alap-és középfokú oktatáshoz. Senkit sem szabad kegyetlen, embertelen vagy lealacsonyitó büntetésnek, vagy bánásmódnak alávetni!

Jelentős, és a legrégebbi történelmi múltban gyökerező értékünk az Igazságosság eszménye. Platón államfelfogásában, társadalmi rendszerében egyenesen ez a legfőbb erény (Kr. előtt V.-IV. század), mibenléte vizsgálatának (osztó és kiegyenlítő igazságosság) munkáiban Arisztotelész is (Kr. e. IV. sz.) nagy figyelmet szentelt, s a középkor (Szt. Tamás, 13. század) a 4 kardinális erény egyikeként tiszteli. (Tamás szerint az igazságosság lényege ebben áll: erős és állhatatos akarattal mindenkinek megadni, ami jogosan megjár neki. ) Mindezek nyomán ma úgy tartjuk, hogy az igazságosság jogi-politikai értelemben az együttélésnek 
olyan normativ, tehát Kell-ést kifejezö alapelve, amely mind az egyéni cselekvés, mind a politikai közösségek és intézmények müködésének legföbb kritériuma! Megvalósítása ezért e vonatkozásban a jogra (törvényhozás, joggyakorlat) tartozik. De közvetve a társadalom olyan informálisan szabályozott közösségeire is vonatkozik, mint a családi, vagy az iskolai közösség. Erénytani megközelítésben az osztó (disztributív) igazságosság az állam és a közösségek, illetve közösségek és egyének viszonyában realizálódik, amennyiben a nagyobb közösség a kisebbnek ill. az egyénnek megadja közjóból az öt megillető részt! A kiegyenlítő v. kompenzatív igazságosság pedig megköveteli, hogy a közjóból a rászorultak, érdemeiktől függetlenül bizonyos, (gyakran minimális) mértékben részesüljenek. És beszélünk egyének egymás közti (kommutatív) igazságosságáról, amely nem a szeretetből, vagy barátságból fakad, hanem az igazság önértékén alapuló elvszerü magatartásból. John Rawls nevéhez füződik a méltányosságként fölfogott igazságosság koncepciója (20. sz . második fele), amely - nagy leegyszerüsítéssel - azt foglalja magában, hogy a társadalmi, és főleg gazdasági egyenlőtlenségeket úgy kell mérsékelni, hogy a legkevésbé előnyös helyzetben lévők számára a legelőnyösebb legyen, olyan elrendezésnek megfelelően, hogy a különböző hivatalok, pozíciók bárki számára elérhetők legyenek..

Az eddig felsoroltak, bár egyetemes érvényüeknek tekintjük, mégis a Nyugat eszményei, s mai demokráciáink alappillérei. Talán nem szükséges külön hangsúlyozni, hogy zsarnoki, diktatórikus avagy totalitáriánus politikai rendszerekben a szabadság, az egyenlőség, az igazságosság, vagy a személy méltóságának eszméjére rákérdezni nemcsak életveszélyes, de egyenesen minden értelmet nélkülöző vállalkozás (bolsevizmus, fasizmus, a mai ÉszakKorea).

A nyugati kultúra, mint láttuk, végső értelemben morális bázissal és arculattal rendelkezik. Főbb alkotóelemei összefoglalóan: a humanizmus, az igazságosság, a (társadalmi-politikai) stabilitás, az érdekkonfliktusok konszenzuális feloldására törekvés, a béke. 'Hát igen, persze, az eszmények - szépek!' szokták volt mondani... de mi közük a mindennapi valósághoz! Ám az eszmények nem (vagy nem feltétlenül) illúziók! Mint olyanok, természetükből adódóan a valósággal szükségképpen mindig (kisebb vagy nagyobb) távolságot képeznek. Az ideális és a reális, a Kellö és ami Van , a Legyen és a Fennálló teljesen sohasem esnek egybe. Az eszmények ugyanis - gondolati konstrukciók -, az alkotó emberi elme teremti meg, a múlt és jelen által többé-kevésbé lehetséges és az önmegvalósításra törekvő ember számára kivánatosnak vélt jövő képei, életünk vezércsillagai. Igazodási pontok, orientálnak, hogy merre menjünk, hogyan éljünk helyesen, egyben jellemünk, cselekvésünk, életünk megítélésnek zsinórmércéi. Megvalósításukra hívnak föl minket: tökéletesedésre, haladásra 
serkentenek: Légy emberséges, légy emberebb ember! Ha tökéletességükben nem tudjuk is az Eszményit a földre hozni, de egyre jobb megközelítésükre folyton törekednünk kell!

A filozófiának, az etikának épp ezért talán legfontosabb küldetése, hogy a valóságos viszonyokat az eszményivel, az elvárhatóval, az ember számára való Jó-val, a kívánatossal ütköztesse. Nem maradhat néma, ha igazságtalanságot, méltánytalanságot, indokolatlan egyenlőtlenséget, emberileg megalázó helyzeteket, viszonyulásokat, döntéseket, gyakorlatokat tapasztal. Minden emberi életszféránkat átszövi az erkölcs, s ezért minden társadalmi alrendszert (és privát életünk terepét is) egyben erkölcsi megítélések tárgyaivá is tesszük. Nincs tiszta, azaz önmagában vett politika, nincs etikai mércéket nélkülözhetö ökonómia. Mert mit ér az olyan politika, mely csak kevesek érdekét, és nem a közjót szolgálja? Amely a hatalmat önmagáért és nem az emberek boldogulásáért akarja? Mit ér az a gazdálkodás, ami csak a növekedés öncélú és gyilkos hajszolására, a profit maximalizálására tör, s nem törődik a vesztesekkel, nem törődik magával az emberrel? Mit ér az olyan élet, ahol nyomor, szenvedés, kilátástalanság, nélkülözés - milliók osztályrésze. Az egykori, 18. századi nyerskapitalizmus új emberképe, a homo oeconomicus, mutatis mutandis- ma is itt kísért: HA, Amennyiben és ameddig hatékony, innovatív, kreatív, vonzó, terhelhető, hasznos és sikeres vagy, addig fontos vagy és számolnak veled. Ha nem, vagy ha MÁR nem, akkor leírnak. Így már nem vagy érték, nem is vagy ember. Utóbbi években épp eme utilitarista felfogás kapcsán szól „a selejtezés kultúrájáról” a katolikus világegyház feje, minden lehetséges közéleti fórumon. 2015 márciusában a Szent Péter téri szokásos általános kihallgatáson (audiencián) a családról szóló katekizmusát folytatta, melyben a hajlott korúak - olyannyira hiányzó - megbecsülésének időszerü fontosságát hangsúlyozta. Ugyanezen év januárjában olasz szerzők tollából (Tornielli-Galeazzi, 2015) könyv jelent meg az egyházfő társadalmi tanításáról: Ferenc pápa: 'Ez a gazdaság öl' címmel. A kötet a föpappal készült interjúval zárul, melyet a La Stampa c. napilap hozott le a munka beharangozásául. Mint ismeretes, Őszentségét a szegénységre, a társadalmi igazságosság súlyos sérülésére vonatkozó szavai, a nélkülözők helyzetére utaló gyakori felhívásai miatt súlyos kritikák, kemény, sőt gúnyolódó támadások érik. Ezek szerint ő volna a marxista, a kommunista pápa. Interjúalanyként azonban a globalizált kapitalizmus kétarcúságára figyelmeztet, mely egyrészt kétség kívül „...sok embernek segített kimenekülni a szegénységből, másrészt azonban embertömegeket ítélt éhhalálra. Összességében növekedett- mondja - a világ gazdagsága, de az egyenlőtlenségek ugyanúgy nőttek és a szegénység újabb formái léptek színre." Szavait továbbra is szó szerint idézve (Ferenc pápa: Gondoskodni a szegényekről...2015): ”... ez a rendszer tartja fenn a selejtezés, a 'szemeteskosár' kultúráját. Létezik a selejtezés politikája és 
szociológiája, valamint egyfajta selejtező magatartás is. Amikor a rendszer középpontjában nem az ember áll többé, hanem a pénz, amikor a pénz bálvánnyá válik, a férfiak és nők csak eszközei annak a gazdasági rendszernek, amelyet nagyarányú egyenlőtlenség jellemez, sőt ural. Így ez a logika „kidobja” mindazt, aminek nem veszi hasznát: ez a hozzáállás dobja ki a gyermekeket /az abortuszokra utal/, és az időseket, és mára ez már a fiatalokat is sújtja. Megdöbbent az a tény, hogy a fejlett országokban több millió olyan, 25 év alatti fiatal él, akinek nincs munkája. Se - se fiataloknak hívják őket, hiszen se nem tanulnak, se nem dolgoznak. Nem tanulnak, mert nincs lehetőségük erre, nem dolgoznak, mert a munkahelyekböl hiány van. Olykor megkérdezem magamtól:

\section{Legközelebb mit fogunk kidobni?}

Időben meg kell állnunk! Álljunk meg! Nem tartjuk a dolgok jelen állását visszafordíthatatlannak, nem törődünk bele!! Egy olyan társadalmat és gazdaságot próbálunk kiépíteni, melyben az ember, és az ő java áll a középpontban, nem a pénz. A piac és a pénzügyi spekulációk nem örvendezhetnek teljes szabadságnak. A szegények problémáinak megoldása nélkül nem lelhetünk a világ problémáira sem megoldást. Olyan programokra, modellekre és folyamatokra van szükség, amelyek elősegítik a források jobb elosztását (lásd: igazságosság elve), a munkahelyteremtést, és a /társadalomból / kirekesztettek ügyének teljes értékü előmozdítását.” (L. Bruni -S. Zamagni: Civil gazdaság - Hatékonyság, Méltányosság, Köz-jóllét c. könyve).

Ahogyan egy humanista, világi alapozású etika is ki kell, hogy álljon az ember, mint önérték, az emberi méltóság védelmében, hasonlóképpen a pápa is, mint személyében egy abszolút érvényű erkölcsi etalon megtestesítője, morálteológiai álláspontról képvisel egy etizált politikát és gazdaságtant.

Persze az erkölcsi szempontok érvényre juttatására való törekvés sohasem önmagában álló, egyedüli, pontosabban nem valamiféle absztrakt, minden más tényezőtől elvonatkoztatott cél. Igen figyelemre méltó, kiterjedt közgazdaságtani kutatások bizonyították a legutóbbi néhány évben (IMF, OECD-elemzések 2014.), hogy a társadalmi egyenlötlenségek növekedése, ami igazságossági-kérdés, és morálisan nem kívánatos, végső értelemben magának a gazdaságnak a teljesítőképességét, össz-jövedelemszerző potenciálját rombolja: egy tartósan alulteljesítő, a fősodortól a versenyben leszakadó gazdaságban a növekedés legfeljebb csak igen szerény és nem-tartós tendencia tud lenni. Viszont már rövid távon a középrétegek leszakadását generálja, s még inkább elmélyíti - kiszélesíti a az alsóbb népcsoportoknál a nyomort. A növekvő egyenlőtlenségek (ezek sokszor újratermelődnek) pl. a nehéz helyzetű családoknál rövidebb oktatási - képzési időtartamot, és a megszerzett képességekben, készségekben 
rosszabb eredményeket hoznak (1. Ferenc pápa megállapítását a fiatalok tömeges munkanélküliségéröl). Az egyenlőtlenségek aláássák az emberek jólétét és jól-létét (azaz: életszínvonalát és életminőségét), és mégis - hangzik az OECD jelentések megállapítása - sok országban olyan erősen jelennek meg, mint évtizedek óta sem!

S ezzel a kör logikailag bezárul: a létbizonytalanság, a nincstelenség, a teljes kilátástalanság, a nélkülözés, a nyomor, (az egyek,vagy fütsek, vagy gyógyszert vegyek?) - nem emberhez méltó élet.

A jó politika, a jó politikai intézkedések azon célja, hogy a gazdagság és szegénység közti szakadékot bezárja, csak akkor tud sikeres lenni, ha a jövedelemelosztás mellett figyelemmel van, pl. a jó oktatáshoz, a jó egészségügyhöz, a közösségi/állami infrastruktúrához való hozzáférésre, s egyáltalán figyelemmel van olyan tényezők és olyan gyakorlatok felszámolására, amelyek okai lehetnek a társadalmi egyenlötlenségek különböző formái keletkezésének, vagy megrögzülésének.

Ilyen egyenlőtlenség-képző elemek pl. az egyes csoportokat különböző sajátosságaik alapján sújtó diszkriminatív, hátrányosan megkülönböztető gyakorlatok (faj, börszín, hitvallás, etnikai hovatartozás, politikai meggyőződés, egészségi állapot, szexuális irányultság, nemi hovatartozás, életkor stb.)

Az utóbbi évtizedekben, nagyjából az 1980-as, 90-es években újfajta egyenlőtlenségkutatások indultak el Nyugaton, amelyek a hagyományos, vertikális (függöleges irányú) egyenlötlenségi felosztások mellett, amelyek a foglalkozási pozíciónak, hivatásbeli státusnak felelnek meg, olyan társalmi helyzet-modelleket irnak le, amelyek horizontális egyenlötlenségek: ilyeneket képeznek, pl. a nem (férfi - női nemhez tartozás), vagy az életkor (idősebbek - korai fiatalok), vagy a Régió, azaz származási hely (kelet-német, vagy nyugatnémet). Ezzel a társadalmi struktúraelemzések területén a réteg- vagy osztályelemzéseket többdimenziós egyenlőtlenségi kutatásokká szélesítették ki. Nyilvánvalóvá vált, hogy az életkor az anyagi és nem anyagi erőforrások egyenlőtlen elosztását, és a kialakult egyenlőtlen helyzet következtében eme erőforrásokhoz való egyenlőtlen hozzájutást is ténylegesen befolyásolja.

Persze valójában nem a biológiai életkori adottságok azok, amelyek itt döntő szerepet játszanak, hanem azok a más korosztályokhoz mért, igazságtalan hátrányt okozó gyakorlatok, amelyek a fiatal, de jellemzően inkább az időskorhoz/korúakhoz kapcsolódó negatív társadalmi viszonyuláson alapulnak: az előítéletes gondolkodáson, a megbélyegzésen, az alulértékelésen, a lenullázáson, a hagyományos időskori szerepklisék kikényszerítésén stb. Ennek megjelenése az ageizmus (a szóalkotással analóg a szexizmus, rasszizmus), azaz az 
életkor szerinti diszkrimináció. A diszkrimináció sérti az egyenlőség és az igazságosság elvét, valamint súlyos önértékelési problémákhoz is vezethet, jelenléte mindig demokrácia-deficitet mutat. Antidiszkriminációs jogszabályokkal, - politikákkal, intézkedésekkel, jogi és morális szankciókkal, egyenlő esélyek teremtésével, társadalmi szemléletváltással küzdünk ellene.

Az egyenlötlenség megnyilvánulhat a nemzedékek közötti hiányzó igazságosságban is, amely generációs konfliktusokat indukálhat. Az érdekek, esélyek ellentétessége, szembenállása és a nemzedékek közötti szocializációs különbözőségek (szokások, élményvilág, értékképzetek, világképek ütközése) nyílt küzdelemhez, háborúskodáshoz vezethet. Ennek feloldására a generációk szolidaritása az emberileg vállalható út mind családi, mind össztársadalmi szinten. (Ezzel szemben lásd: Stiftung für die Rechte zukünftiger Generationen, Stuttgart, 1997.) A szolidaritás, melyen lényegileg a generációk közötti kölcsönös támogatást, tudás és képességek transzferjét értjük).

A vívmányait (nyugati értékeit) oly következesen és elszántan megőrizni kívánó Európai Unió (a lakosság drasztikus elöregedése ellenére is) a humánértékek és a jólléti státus fenntartása érdekében rendszeresen uniós programokat, éves akciókat indít (2007: Esélyek éve, egyenlő esélyeket mindenkinek, 2012. Aktív időskor és a nemzedékek szolidaritása).

Míg a korábbi évtizedekben (1970-es években ) a jelenleg „régi öregek” (a ’restli') szociális helyzetén felülről, állami támogatások nyújtásával próbáltak javítgatni, most az „önsegítő elv” követése került az uniós időspolitika előterébe. Annak érdekében, hogy a szociális ellátó rendszerek minden mértéken felüli túlterhelését, netán teljes összeomlását elkerüljük, hogy a társadalmi kohéziót fenntartsuk, és az egyén számára is egy jobb minőségű, boldogabb, sikeresebb időskor esélyét nyújthassuk, egy proaktív és támogató időspolitika koncepciójának megfogalmazására és kidolgozására került sor uniós és tagországi szinten. Már ahol (Eszköze: Helyzetbe hozni az időseket! Kiaknázni a még bennük rejlő pozitív lehetőségeket, értékeket.) Ez a korszerü tudástartalmakhoz való hozzáférés, oktatás - élethosszig tartó tanulás, digitális írástudás, az egészségvédelem, helyes táplálkozás, munkahelyi és/ vagy közéleti aktivitás, szabadidős- rekreációs programok, idősekkel kapcsolatos társadalmi szemléletváltás: kirekesztés helyett befogadás, nyugdíjreform, generációs szolidaritás stb. kulcsszavaival írható le. A „mai öregek” már sokkal öntudatosabbak, lendületesebbek, kezdeményezőbbek, nyitottabbak az újra, az önképzésre, a korszak kihívásaira, a megváltozott külső feltételrendszerekhez való rugalmasabb alkalmazkodásra.

Mindezekhez persze tegyük hozzá: az idősek korosztálya messze nem homogén csoport (egyéni egészségi állapot, családi állapot, lakóhely, korábbi évtizedek munkája általi 
igénybevétel, anyagi helyzet) - mindez meghatározza a sikeres öregedésre vonatkozó/felkínált esélyeinket.

Az öregedés, az öregség, a hozzá való viszonyulás nem magánügy, bár individuálisan is előbb vagy utóbb valamennyiünknek szembesülnünk kell vele. Nem csak az érintettekre, mindannyiunkra tartozik. Az idősekben jövőbeni önmagunkat, sorsukban az eljövendő évek árnyait vagy szépségét, értelmességét pillanthatjuk meg.

Simone de Beauvoir, Jan-Paul Sartre 20. századi francia egzisztencialista filozófus élettársa az 1970-es évek elején mintegy 700 oldal terjedelmü könyvet írt az Öregségről. Az öregség állapítja meg - tabu, szégyellni való, össztársadalmi hallgatás veszi körül. Ez azt jelzi, hogy rossz velük kapcsolatban a társadalom lelkiismerete.

Ne hagyjuk, hogy ez napjainkban továbbra is így legyen! Teljes egyetértéssel idézhetjük egy magyar internetes kommentelő megállapításait 2015-ből a jelzett mü kapcsán. Így ír:

„Ez az a könyv, amit legalább háromszor el kellene olvasnia mindenkinek. Először tizenéves korában, hogy megértsék az öregeket, ne legyenek számukra szenilis vén marhák, akik csak a helyet foglalják feleslegesen a villamoson (bár akkor még nem hiszik, de rájuk is az ő sorsuk vár, ha nem rosszabb). Másodszor, mikor félúton állnak öregség és fiatalság között. Egyrészt, hogy fel tudjanak készülni az öregségre, másrészt azért, hogy megfelelően bánjanak megöregedett szüleikkel és valóban segíteni tudjanak nekik ebben az állapotukban. Harmadszor pedig, amikor az ember megöregszik, és szembe kell nézzen mindazzal, ami ebben a könyvben le van írva. Igyekezzen elkerülni a csapdákat, gondolkozzon azon, vizsgálódjon, vajon reálisan méri fel a dolgokat? Saját magát? Érzelmeit? Hogy igenis barátkozzon, szeressen, alkosson, legyenek céljai egészen a haláláig, sőt azon túlra is.”

Hogy igenis barátkozzon, szeressen, alkosson, legyenek céljai egészen a halálig, söt azon túlra is!

\section{Irodalom:}

1. Beauvoir, de Simone (1972): Az öregség. Európa Kiadó, Budapest (Fordította Pődör László) ISBN: -

2. Brunni, Luigiano-Zamani, Stefano (2013): Civil gazdaság. - Hatékonyság, Méltányosság, Közjóllét. L' Harmattan Kiadó, Budapest (fordította Osvay Péter) ISBN: 789632366715

3. Illyés Gyula (1976): Kháron ladikján, vagy az öregedés tünetei, Szépirodalmi Könyvkiadó, Budapest, ISBN:963 1505677 
4. Márai Sándor (2003): Kassai őrjárat, Helikon Kiadó, Budapest, 121.o.ISBN: 9632088395

5. Tornielli, Andrea-Galeazzi, Giacomo (2015): Ferenc pápa. Ez a gazdaság öl. Jezsuita Kiadó, Budapest, ISBN: 9789638014771

\section{Elektronikus források:}

Ferenc pápa: Gondoskodni a szegényekről nem kommunizmus, hanem evangélium

http://www.magyarkurir.hu/nezopont/gondoskodni-szegenyekrol-nem-kommunizmus-hanem-

Morpheus, kiemelt értékelések Beuvoir az öregség c. könyvéröl:

https://moly.hu/konyvek/Simone.de-Beauvoir-az -

\section{Prof. Dr. Hell Judit}

Miskolci Egyetem, Bölcsészettudományi Kar, Antropológiai és Filozófiai Tudományok Intézete

Elérhetőség: 3530 Miskolc, Király u. 7., helljudit54@gmail.com, 06/70/6143555 